Cover. Iron staining around an irrigation well that withdraws groundwater from the Mississippi River Valley alluvial aquifer near Tiptonville, Tennessee. Photograph by Benjamin Miller, U.S. Geological Survey. 


\section{Machine-Learning Predictions of Redox Conditions in Groundwater in the Mississippi River Valley Alluvial and Claiborne Aquifers, South-Central United States}

By Katherine J. Knierim, James A. Kingsbury, and Connor J. Haugh

National Water Quality Program

Pamphlet to accompany

Scientific Investigations Map 3468 


\section{U.S. Geological Survey, Reston, Virginia: 2021}

For more information on the USGS - the Federal source for science about the Earth, its natural and living resources, natural hazards, and the environment-visit https://www.usgs.gov or call 1-888-ASK-USGS.

For an overview of USGS information products, including maps, imagery, and publications, visit https://store.usgs.gov.

Any use of trade, firm, or product names is for descriptive purposes only and does not imply endorsement by the U.S. Government.

Although this information product, for the most part, is in the public domain, it also may contain copyrighted materials as noted in the text. Permission to reproduce copyrighted items must be secured from the copyright owner.

Suggested Citation:

Knierim, K.J., Kingsbury, J.A., and Haugh, C.J., 2021, Machine-learning predictions of redox conditions in groundwater in the Mississippi River Valley alluvial and Claiborne aquifers, south-central United States: U.S. Geological Survey Scientific Investigations Map 3468, 16 p., 3 sheets, https://doi.org/10.3133/sim3468.

Associated data for this publication:

Knierim, K.J., Kingsbury, J.A., and Haugh, C.J., 2020, Machine-learning model predictions and rasters of dissolved oxygen probability, iron concentration, and redox conditions in groundwater in the Mississippi River Valley alluvial and Claiborne aquifers: U.S. Geological Survey data release, https://doi.org/10.5066/P9N108JM. 


\section{Contents}

Abstract

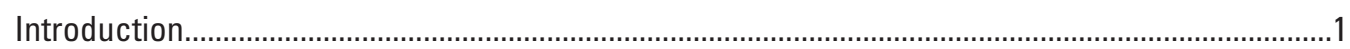

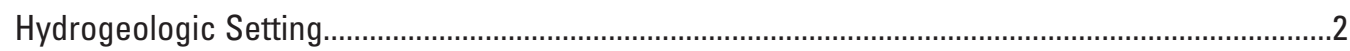

Methods

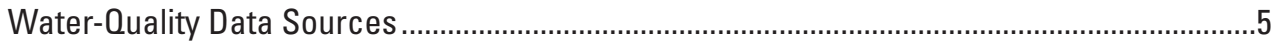

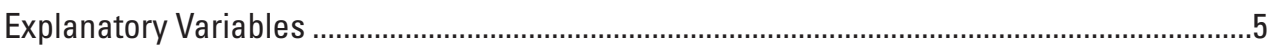

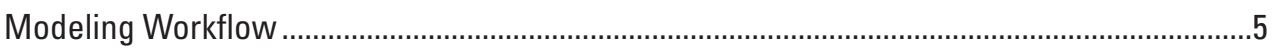

Mapping of Oxidation-Reduction (Redox) Zones ..............................................................

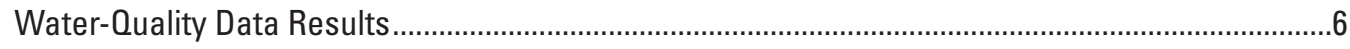

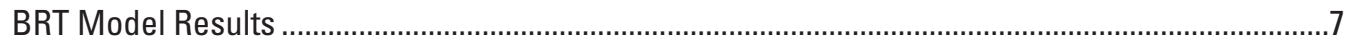

Predictions of Dissolved Oxygen Threshold Probabilities ..............................................................

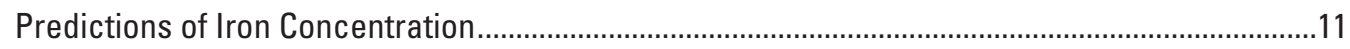

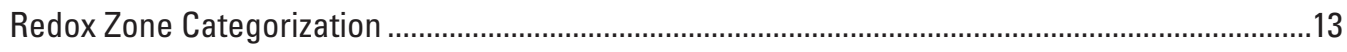

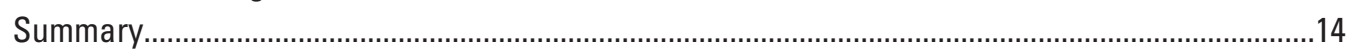

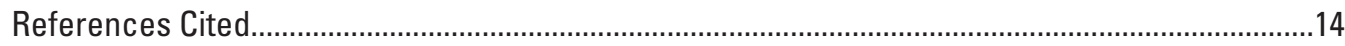

\section{Figures}

1. Map and chart showing principal aquifers of the Mississippi embayment physiographic region, including the Mississippi River Valley alluvial aquifer and units of the Mississippi embayment aquifer system.

2. Cross sections showing regional aquifers and groundwater-flow model layers in the Mississippi embayment from Clark and Hart.

3. Maps showing location of wells with dissolved oxygen data used in machine-learning models.

4. Maps showing location of wells with iron concentration data used in machine-learning models

5. Boxplots showing dissolved oxygen and iron concentrations in groundwater wells by hydrogeologic unit.

6. Graph showing observed dissolved oxygen (DO) concentration in groundwater wells versus predicted DO probability in wells and at raster cells coincident with wells, and boxplot showing observed DO threshold category in groundwater wells versus predicted DO probability in wells and at raster cells coincident with wells.

7. Graphs showing observed versus predicted iron concentration back-transformed to units of micrograms per liter, and observed versus predicted natural log iron concentration.

8. Maps showing predicted probabilities of dissolved oxygen concentration exceeding a threshold of 1 milligram per liter... ...sheet 1

9. Graph showing relative influence of explanatory variables in the dissolved oxygen model

10. Maps showing predicted iron concentrations .......................................................sheet 2

11. Graph showing cumulative distribution frequency of observed iron concentrations at wells, predicted iron concentrations at wells, and predicted iron concentrations at raster cells coincident with wells

12. Graph showing relative influence of explanatory variables in the iron model ...............12

13. Maps showing predicted redox zones.............................................................................. 3 


\section{Sheets}

[Available for download at https://doi.org/10.3133/sim3468]

Sheet 1

Sheet 2

Sheet 3

\section{Tables}

1. Model layers used in this study for mapping machine-learning predictions across Mississippi River Valley Alluvial, middle Claiborne, and lower Claiborne aquifers compared to MODFLOW groundwater flow-model layers from Clark and Hart.

2. Redox zone categories based on predicted probability of dissolved oxygen concentration exceeding a threshold of 1 milligram per liter and based on iron concentration.

3. Hyperparameters for dissolved oxygen and iron boosted regression tree models for the final, variable reduced, one standard error, and best training models .8

4. Observed and predicted dissolved oxygen events for holdout data .8

\section{Conversion Factors}

U.S. customary units to International System of Units

\begin{tabular}{ccc}
\hline Multiply & By & To obtain \\
\hline foot $(\mathrm{ft})$ & 0.3048 & meter $(\mathrm{m})$ \\
\hline
\end{tabular}

\section{Datum}

Vertical coordinate information is referenced to the National Geodetic Vertical Datum of 1929 (NGVD 29).

Horizontal coordinate information is referenced to the North American Datum of 1983 (NAD 83). Altitude, as used in this report, refers to distance above the vertical datum.

\section{Supplemental Information}

Concentrations of chemical constituents in water are given in either milligrams per liter (mg/L) or micrograms per liter $(\mu \mathrm{g} / \mathrm{L})$. 


\section{Abbreviations}

\begin{tabular}{|c|c|}
\hline 1SE & one standard error \\
\hline AUROC & $\begin{array}{l}\text { area under the receiver operating characteristic } \\
\text { curve }\end{array}$ \\
\hline BRT & boosted regression tree \\
\hline $\mathrm{Cl}$ & confidence interval \\
\hline DO & dissolved oxygen \\
\hline LCAO & lower Claiborne aquifer \\
\hline MCAO & middle Claiborne aquifer \\
\hline $\mathrm{ML}$ & machine learning \\
\hline MRVA & Mississippi River Valley alluvial aquifer \\
\hline $\mathrm{PI}$ & prediction interval \\
\hline $\mathrm{ppb}$ & percent proportion bias \\
\hline$r^{2}$ & coefficient of determination \\
\hline RMSE & root mean square error \\
\hline
\end{tabular}





\title{
Machine-Learning Predictions of Redox Conditions in Groundwater in the Mississippi River Valley Alluvial and Claiborne Aquifers, South-Central United States
}

\author{
By Katherine J. Knierim, James A. Kingsbury, and Connor J. Haugh
}

\section{Abstract}

Machine-learning models developed by the U.S. Geological Survey were used to predict iron concentrations and the probability of dissolved oxygen (DO) concentrations exceeding a threshold of 1 milligram per liter $(\mathrm{mg} / \mathrm{L})$ in groundwater in aquifers of the Mississippi embayment physiographic region. DO and iron concentrations are driven by and reflect the oxidation-reduction (redox) conditions in groundwater. Predictions from boosted regression trees, a type of machine-learning model, of iron concentration and DO threshold probability were used to categorize redox zones in the Mississippi River Valley alluvial aquifer (MRVA), middle Claiborne aquifer (MCAQ), and lower Claiborne aquifer (LCAQ). Model predictions indicated that DO concentrations greater than $1 \mathrm{mg} / \mathrm{L}$ are uncommon across the MRVA. DO events (where the predicted probability was greater than 0.5 ) tended to occur on the margins of the MRVA and in upland areas where MCAQ and LCAQ units crop out at the surface or are at shallow depth. Predicted iron concentrations were higher in the MRVA than in the MCAQ and LCAQ. Uncertainty in predicted iron concentrations tended to be high in areas where measured concentrations were also high, resulting in small areas (encompassing less than 1.5 percent of the areal extent of the MRVA) of predicted iron concentrations that exceeded 100,000 micrograms per liter. Despite the large magnitude of overpredicted iron concentrations, the general proportion and spatial distribution of predicted iron concentrations reflected observed concentrations in groundwater wells. Where the probability of exceeding a DO concentration of $1 \mathrm{mg} / \mathrm{L}$ was 0.8 or more and the iron concentration was less than 1,000 micrograms per liter, aquifers were categorized as oxic. Oxic conditions were mostly in the uplands where MCAQ and LCAQ units crop out at the margins of the modeled area. The MRVA was mostly anoxic, which was controlled by DO threshold probabilities less than 0.1 . The predictions and redox zones support conceptual models of redox conditions in the Mississippi embayment. The MRVA is predominantly anoxic with high iron concentrations. In the Claiborne aquifers (including the MCAQ and LCAQ), groundwater flows along regional flow paths toward the axis of the Mississippi embayment (the approximate location of the Mississippi River), the residence time in the aquifer increases, DO is consumed, and iron concentrations generally increase. Elevated concentrations of trace elements, such as manganese and arsenic, are often associated with reducing conditions in anoxic and mixed anoxic zones, but other factors such as sediment mineralogy affect the occurrence and distribution of these constituents.

\section{Introduction}

Aquifers in the Mississippi embayment physiographic region of the south-central United States are vital sources of water used for a variety of purposes, primarily for drinking water and irrigation (Maupin and Barber, 2005). As use of these aquifers has increased over time, questions related to long-term availability of water have gained importance (Clark and others, 2011), and one aspect affecting the availability of water for designated use is water quality. Overall groundwater quality in aquifers of the Mississippi embayment is good, with few contaminants above drinking water standards or health-based concentration benchmarks (Kingsbury and others, 2015). However, high concentrations of some trace elements (including iron and manganese) require treatment for use as drinking water and contribute to fouling of equipment used to pump and distribute groundwater for irrigation.

The concentration of trace elements in groundwater is largely driven by oxidation-reduction (redox) processes. Redox processes are a group of biotically driven reactions in which energy is derived from the exchange of electrons. In groundwater, this commonly occurs through decomposition of organic matter (carbon) by microbes, which consume dissolved oxygen (DO) (McMahon and Chapelle, 2008). Under low DO (anoxic) conditions, iron, manganese, and other associated trace elements such as arsenic can dissolve from coatings on aquifer sediments and be released into groundwater. Therefore, an ability to accurately predict redox conditions is important to better understand the potential distribution of trace elements in drinking-water aquifers. To address this 
need, the U.S. Geological Survey developed machine-learning (ML) models to predict iron concentration and the probability of exceeding a DO threshold of 1 milligram per liter $(\mathrm{mg} / \mathrm{L})$ in groundwater of the Mississippi embayment. The ML predictions were used to categorize groundwater into redox zones. This report documents the development of ML models to categorize redox conditions in groundwater in aquifers of the Mississippi embayment, including the Mississippi River Valley alluvial and Claiborne aquifers.

\section{Hydrogeologic Setting}

The Mississippi embayment includes two principal regional aquifer systems: the surficial Mississippi River Valley alluvial aquifer (MRVA) and the Mississippi embayment aquifer system, which includes deeper Tertiary-age sediments (fig. 1). Based on the distribution of groundwater used for drinking water, the modeling focused on the MRVA and two Claiborne aquifers, the middle Claiborne aquifer (MCAQ) and lower Claiborne aquifer (LCAQ). These hydrogeologic units are composed of unconsolidated clastic sediments of gravel, sand, silt, and clay deposited throughout the Cenozoic (Tertiary and Quaternary) (Clark and Hart, 2009). The MRVA includes Pleistocene and Holocene gravel, sands, silts, and clays with a generally upward fining sequence (Hart and others, 2008) and textural zones that correspond to geomorphic provinces of fluvial deposits of the Mississippi River (Saucier, 1994). The thickness and extent of the MCAQ and LCAQ vary by location across the northern and southern regions of the Mississippi embayment.

In the south, the stratigraphy of the LCAQ predominantly consists of sand deposits with interbedded silt and clay, and is primarily composed of the Carrizo Sand in Arkansas and Louisiana, the Meridian Sand in Mississippi, and Meridian Sand Member of the Tallahata Formation in Alabama (Hart and others, 2008). The LCAQ unit is separated from the MCAQ — which consists mostly of the Sparta Sand - by the lower Claiborne confining unit. North of approximately the 35th parallel (near the Tennessee-Mississippi State line), this confining unit undergoes a facies change such that the MCAQ and LCAQ become a single unit, referred to as the Memphis Sand; the LCAQ does not extend north of the 35th parallel (figs. 1 and 2; Hosman and Weiss, 1991). For this modeling effort, the base of the MCAQ in the northern part of the study area is referred to as "LCAQ-equivalent," because MODFLOW groundwater-flow model layers (that is, model layers 9 and 10) extend across the entire study area. Table 1 shows the relationship between hydrogeologic units from the MODFLOW model (Clark and Hart, 2009) and the layers used to map ML predictions from this modeling effort.

Differences in groundwater quality between the MRVA and Claiborne aquifers largely reflect differences in the sediments that compose the aquifers and the organic carbon content of those sediments. The MRVA has mostly low DO concentrations (fig $3 A$ on sheet 1 ) and elevated concentrations of trace elements (Borrok and others, 2018). In contrast, DO concentration varies across the Claiborne aquifers (fig $3 B$ on sheet 1 ) and iron concentrations are generally low (fig. $4 B$ on sheet 2; Kingsbury and others, 2015; Kresse and others, 2014). The formations that contain the Claiborne aquifers consist primarily of quartz sand and minor amounts of disseminated lignite (Parks and Carmichael, 1990). In contrast, the sediments that compose the MRVA are heterogeneous (Sharif and others, 2008) and contain considerably more organic material. As a result, groundwater in the MRVA generally has higher specific conductance (total dissolved solids), lower DO concentrations, and more reducing conditions than groundwater in the MCAQ and LCAQ (Kingsbury and others, 2015).

\section{Methods}

Various ML methods have been used to predict water-quality constituents and successfully map the predictions across groundwater aquifers (DeSimone and others, 2020; Knierim and others, 2020b; Nolan and others, 2015; Ransom and others, 2017; Rosecrans and others, 2017). ML methods are suitable for making predictions in hydrologic systems, because the machine algorithm identifies patterns in explanatory variable datasets to predict a response variable (Kuhn and Johnson, 2013). Redox zones were mapped in aquifers of the Mississippi embayment region using a categorization scheme based on predictions from two ML models. The ML models use an ensemble method, boosted regression trees (BRT), which minimizes a loss function (such as model accuracy or error) using boosting of model residuals (Friedman, 2001; Kuhn and Johnson, 2013). BRT models have the advantage of accepting missing values (Elith and others, 2008), which is important when predicting "wall-to-wall" across aquifer systems because missing values in explanatory variable datasets are common.

To categorize redox zones, the probability of DO concentration exceeding a threshold of $1 \mathrm{mg} / \mathrm{L}$ was predicted with a classification BRT model, and iron concentration was predicted with a regression BRT model. The smaller dataset size for DO concentration required a classification model, where a DO concentration less than or equal to $1 \mathrm{mg} / \mathrm{L}$ is classified as a nonevent and a DO concentration greater than $1 \mathrm{mg} / \mathrm{L}$ is classified as an event. Although a DO concentration of $0.5 \mathrm{mg} / \mathrm{L}$ is used as a typical threshold for anoxic conditions, for the Mississippi embayment, iron concentration showed greater separation between DO concentrations above and below $1 \mathrm{mg} / \mathrm{L}$ compared to $0.5 \mathrm{mg} / \mathrm{L}$, such that $1 \mathrm{mg} / \mathrm{L}$ was used as the classification model threshold. The BRT classification model predicts the probability of an event, and predicted probabilities greater than 0.5 are considered predicted events. Accuracy (or the correct prediction of events and nonevents) is maximized in BRT classification models. Natural logs of iron concentrations were predicted with a regression 


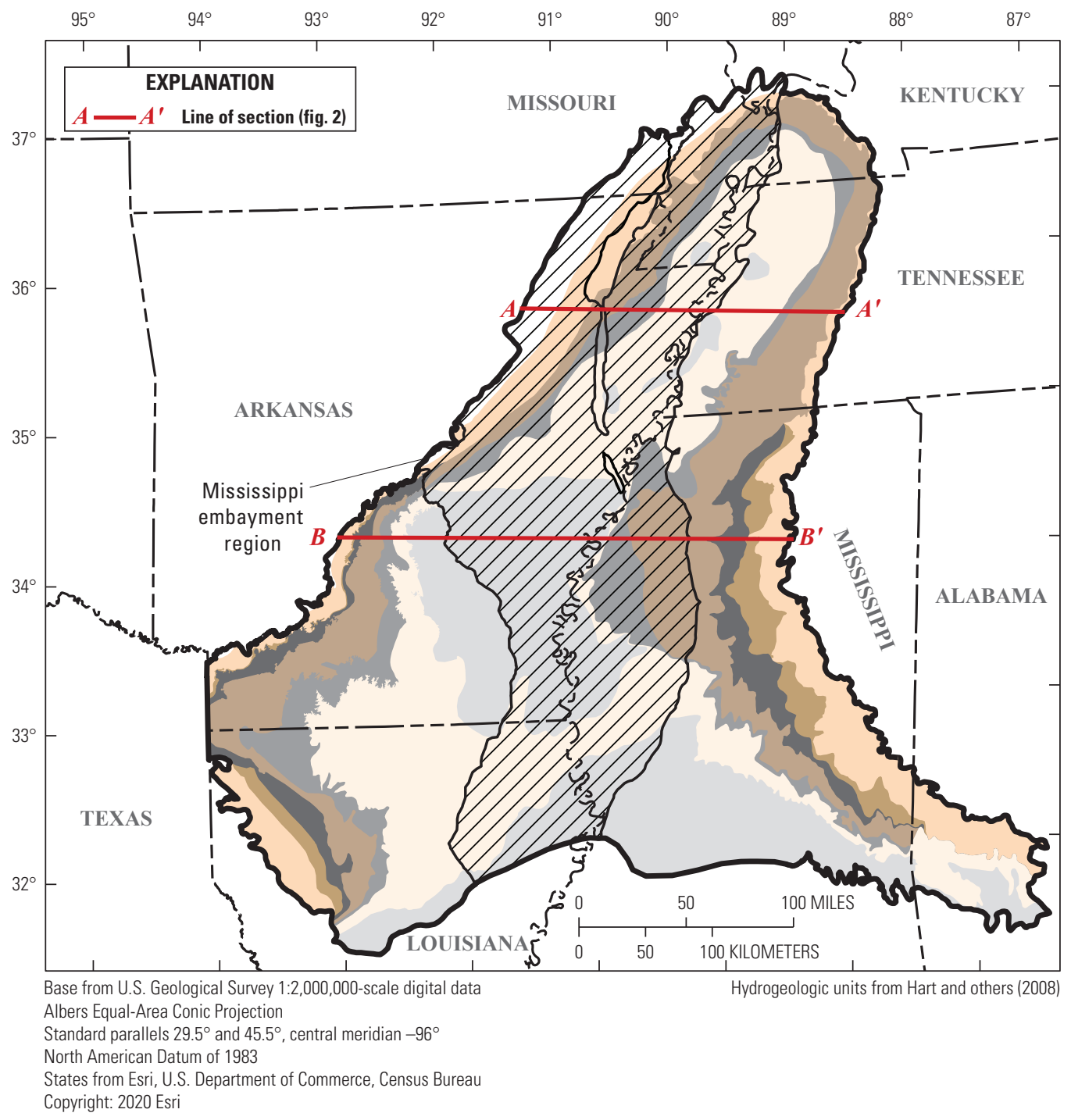

\begin{tabular}{|c|c|c|c|}
\hline \multirow{2}{*}{$\begin{array}{l}\text { Principal } \\
\text { aquifer }\end{array}$} & \multicolumn{2}{|c|}{ Age } & \multirow{2}{*}{ Hydrogeologic units } \\
\hline & System & Epoch & \\
\hline MRVA & Quaternary & $\begin{array}{c}\text { Holocene } \\
\text { Pleistocene }\end{array}$ & WIIA Mississippi River Valley alluvial aquifer \\
\hline \multirow{7}{*}{ 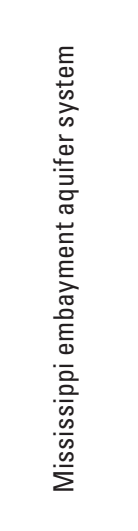 } & \multirow{7}{*}{ Tertiary } & Oligocene & $\square$ Vicksburg-Jackson confining unit \\
\hline & & \multirow{5}{*}{ Eocene } & $\square$ Upper Claiborne aquifer \\
\hline & & & $\square$ Middle Claiborne confining unit \\
\hline & & & $\square$ Middle Claiborne aquifer \\
\hline & & & Lower Claiborne confining unit \\
\hline & & & $\square$ Lower Claiborne aquifer \\
\hline & & $\begin{array}{c}\text { Upper } \\
\text { Paleocene }\end{array}$ & Middle Wilcox aquifer \\
\hline
\end{tabular}

Figure 1. Principal aquifers of the Mississippi embayment physiographic region, including the Mississippi River Valley alluvial aquifer (MRVA) and units of the Mississippi embayment aquifer system. Hydrogeologic units and ages from Hart and others (2008). 

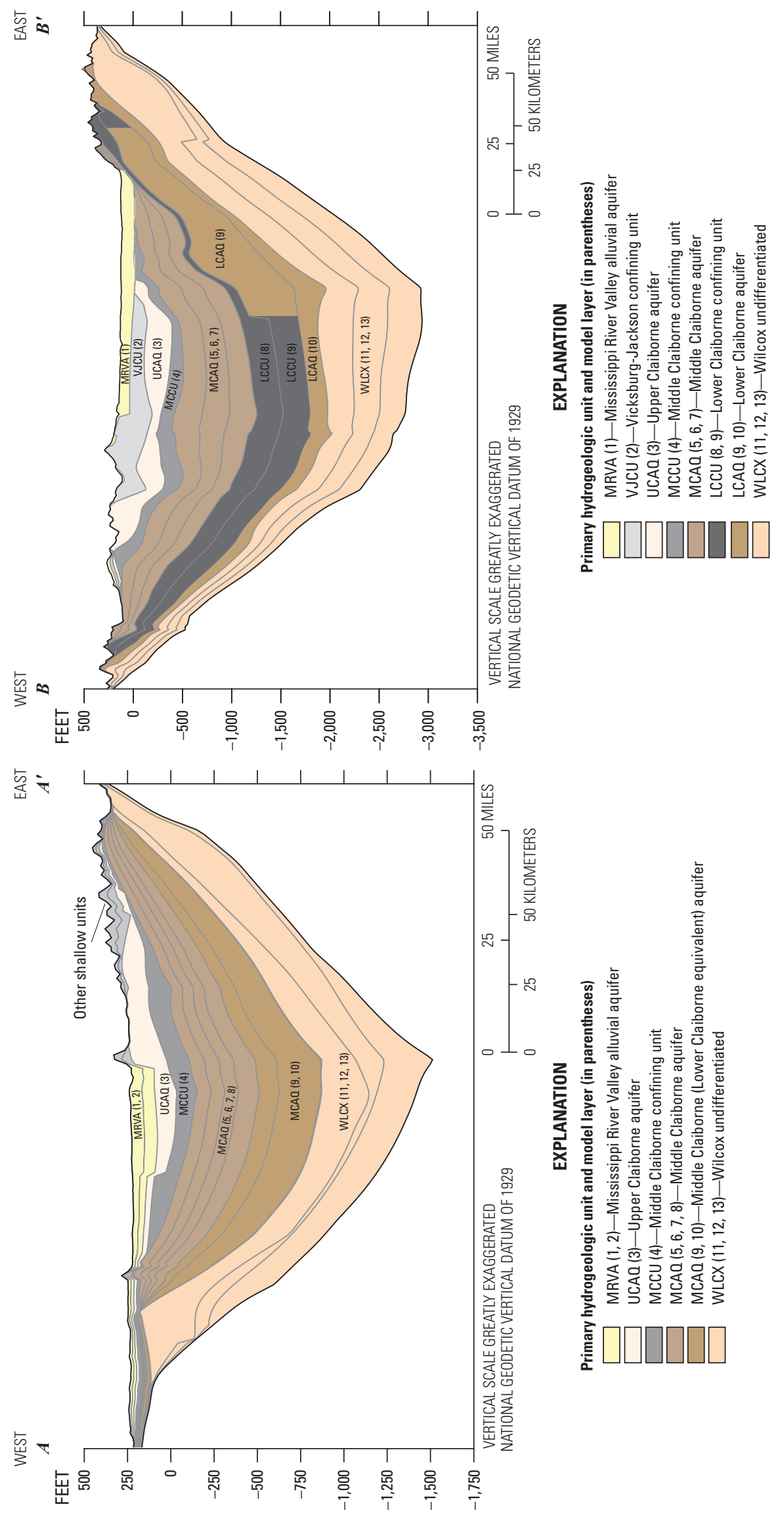

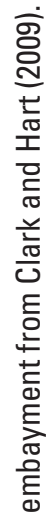

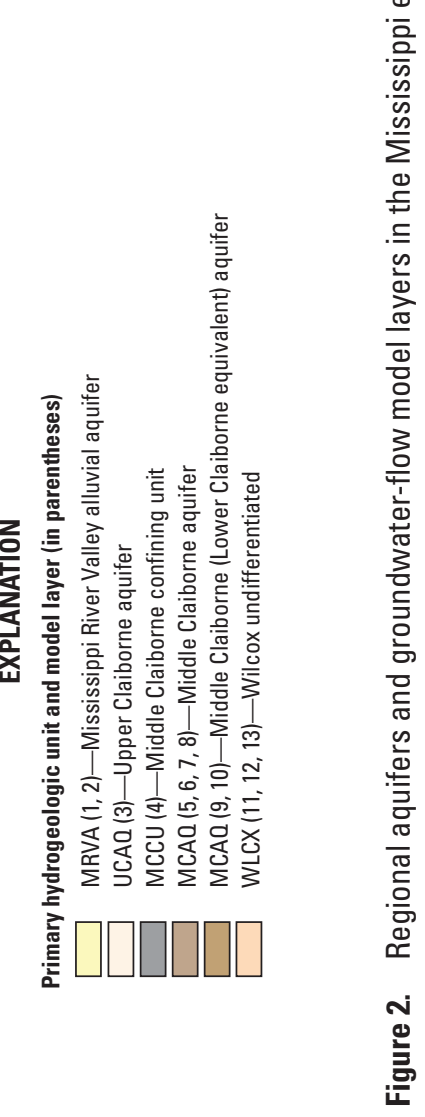


Table 1. Model layers used in this study for mapping machine-learning (ML) predictions across Mississippi River Valley Alluvial (MRVA), middle Claiborne (MCAO), and lower Claiborne (LCAO) aquifers compared to MODFLOW groundwater flow-model layers from Clark and Hart (2009).

[min, minimum; max, maximum]

\begin{tabular}{|c|c|c|c|c|c|c|}
\hline \multirow{2}{*}{$\begin{array}{c}\text { Hydrogeologic } \\
\text { unit }\end{array}$} & \multirow{2}{*}{$\begin{array}{l}\text { MODFLOW } \\
\text { model layers }\end{array}$} & \multirow{2}{*}{$\begin{array}{l}\text { ML model } \\
\text { layers }\end{array}$} & \multicolumn{4}{|c|}{ Depth ranges (feet) } \\
\hline & & & $\operatorname{Min}^{2}$ & $\begin{array}{c}\text { 10th } \\
\text { percentile }\end{array}$ & $\begin{array}{c}\text { 90th } \\
\text { percentile }\end{array}$ & Max \\
\hline MRVA & $1-2$ & 1 & -10 & 85 & 164 & 256 \\
\hline MCAQ & $5-10$ & $5-8$ & -39 & 79 & 1,024 & 2,612 \\
\hline LCAQ & $9-10$ & $9-10$ & -33 & 213 & 1,808 & 3,360 \\
\hline
\end{tabular}

${ }^{1}$ From Clark and Hart (2009).

${ }^{2} 0.1$ percent of raster cells have negative depths (below zero) because a more recent digital elevation model (DEM; U.S. Geological Survey, 2016) was used in this study than the DEM used in Clark and Hart (2009) to determine the altitude of the top of the MODFLOW groundwater-flow model.

BRT model, which minimizes root mean square error (RMSE). For both ML models, percent proportion bias (ppb) was also used as a metric to evaluate model performance, where $\mathrm{ppb}$ was calculated as

$$
\begin{aligned}
& \operatorname{ppb}(\text { continuous regression })=100 \times \\
& \Sigma(\text { predicted }- \text { observed }) / \text { इobserved }
\end{aligned}
$$

and

$$
\begin{aligned}
& \begin{array}{l}
p p b(\text { classification })=100 \times \\
(\text { number of observed events }) /(\text { number of samples })
\end{array} \\
& \text { (number of predicted events }) /(\text { number of samples })
\end{aligned}
$$

Output from BRT models was used to map the probability of exceeding a DO concentration of $1 \mathrm{mg} / \mathrm{L}$, iron concentrations, and qualitative redox zones in drinking-water aquifers of the Mississippi embayment.

\section{Water-Quality Data Sources}

DO and iron concentration data were compiled from several sources to maximize the number and spatial distribution of samples: the National Water Information System (NWIS) database of the U.S. Geological Survey (U.S. Geological Survey, 2017), Groundwater Ambient Monitoring Networks maintained by State agencies, and the Safe Drinking Water Information System maintained by the U.S. Environmental Protection Agency (U.S. Environmental Protection Agency, 2013). DO concentration data spanned 1978-2019, and iron concentration data spanned 1960-2019. Samples were collected from public supply, domestic, irrigation, industrial, and monitoring wells. For wells sampled more than once, data from the most recent samples were used. Because the most recent data were used and groundwater flow paths are long ( $>100$ years) throughout much of the study area (Haugh and others, 2020c; Kingsbury and others, 2017), the possible effects of changes in water quality over time were considered small compared to the improvement in overall model accuracy obtained by using available historical data.

\section{Explanatory Variables}

Explanatory variables for the BRT models (Knierim and others, 2020a) included attributes associated with well geometry, namely location and construction information, including aquifer, well depth, and screen altitude; surficial variables, such as soils and land use; and variables extracted from a MODFLOW-2005 groundwater-flow model for the Mississippi embayment (Haugh and others, 2020a, b, c). Explanatory variables were acquired from a variety of data sources or derived from the hydrogeologic framework for the Mississippi embayment (Hart and others, 2008) using well metadata. Prior to their use in the BRT models, explanatory variable datasets were preprocessed to remove variables having a linear correlation greater than 0.8 , which reduced the number of explanatory variables from 225 to 130 for DO and 132 for iron (which included modeled specific conductance and DO predictions as explanatory variables). Rasters of explanatory variables were attributed to groundwater wells using Python software (Python Software Foundation, 2019). For a full description of explanatory variables, preprocessing, and attribution, see Knierim and others (2020b).

\section{Modeling Workflow}

For both DO and iron models, the modeling workflow followed that of Knierim and others (2020b). In brief, the response data - either DO event/nonevent categories or natural $\log$ of iron concentration - and corresponding explanatory 
variables were split into training ( 80 percent) and holdout (20 percent) datasets. The BRT model was tuned to find the combination of hyperparameters that produced a model having either the highest accuracy (DO) or lowest RMSE (iron), referred to as the "best" model. Tuning was completed using tenfold cross-validation in the statistical programming software R (R Core Team, 2019) with the caret and gbm packages (Kuhn and others, 2019; Ridgeway, 2019). After the model was tuned, a one-standard-error (1SE) routine developed by Nolan and others (2015) was used to find simpler models (in which complexity is defined by the hyperparameters) within $1 \mathrm{SE}$ of the "best" model's RMSE or accuracy. Once the hyperparameters for the 1SE model were selected that provided a balance between low ppb and either high accuracy or low RMSE, a variable-reduction routine developed by Ransom and others (2017) was used to remove explanatory variables that did not improve model performance, again based on high accuracy (DO) or low RMSE (iron) and low ppb.

Once the "final" BRT model was selected, predictions were made at groundwater wells, and prediction mapping was completed using raster grids of all explanatory variables remaining in the final model. The depth for each prediction layer was the midpoint altitude of the corresponding MODFLOW groundwater-flow model layer, such that seven prediction layers were produced — one for MRVA, four for MCAQ, and two for LCAQ - for DO threshold probabilities and iron concentrations (table 1). Iron was backtransformed from natural log space to real units of micrograms per liter using a bias correction factor (Duan, 1983; Nolan and others, 2015). Uncertainty was quantified via confidence intervals (CIs) for DO and prediction intervals (PIs) for iron following a bootstrapping routine developed by Ransom and others (2017) in which model hyperparameters were held constant and tree structure, such as split variables, split levels at nodes, and prediction at terminal nodes, was allowed to vary. DO CIs are constrained between 0 and 1 , as is the case for the probability predictions. Similarly, iron PIs are in the same concentration units as the predictions, namely micrograms per liter. Details about modeling workflow, including tuning, 1SE model selection, variable reduction loop, and uncertainty bootstrapping, are provided in Knierim and others (2020b).

\section{Mapping of Oxidation-Reduction (Redox) Zones}

Redox zone rasters were created to describe general redox conditions in Mississippi embayment aquifers for four zones: anoxic, mixed anoxic, mixed oxic, and oxic, using the $\mathrm{DO}$ and iron predictions from BRT models. DO and iron were used in combination to categorize redox zones because the DO dataset size is relatively small $(451)$ compared to iron $(1,408)$. Additionally, although DO concentration is an appropriate first approximation for categorizing redox conditions, DO concentration alone does not indicate where along the terminal electron acceptor sequence the groundwater may be; that is, how reducing it is. Iron can be used to further describe redox conditions, because it has a widespread sample distribution and is both influenced by and an important indicator of redox conditions.
Oxic conditions include areas where the probability of exceeding a DO concentration of $1 \mathrm{mg} / \mathrm{L}$ was greater than 80 percent. Anoxic conditions include areas where the probability of exceeding a DO concentration of $1 \mathrm{mg} / \mathrm{L}$ was less than 10 percent. Mixed conditions include anywhere that the predicted DO threshold probability was greater than or equal to 10 percent and less than or equal to 80 percent, and iron concentrations were either less than 500 micrograms per liter $(\mu \mathrm{g} / \mathrm{L})($ mixed oxic) or greater than or equal to $500 \mu \mathrm{g} / \mathrm{L}$ (mixed anoxic). Any areas that were characterized as oxic but had iron concentrations greater than $1,000 \mu \mathrm{g} / \mathrm{L}$ were recategorized as mixed oxic. Elevated iron concentrations generally indicate reducing conditions (Chapelle and others, 1995), such that mixed redox conditions (and specifically mixed oxic) are more plausible than oxic conditions. Previous work categorized principal aquifers nationally using a DO concentration threshold of $0.5 \mathrm{mg} / \mathrm{L}$ and an iron concentration threshold of $100 \mu \mathrm{g} / \mathrm{L}$ (McMahon and Chapelle, 2008). However, the classifications were meant to provide national consistency for aquifers with varying geology, and thresholds may differ with site-specific information (McMahon and Chapelle, 2008). The classifications provided here are specific to aquifers of the Mississippi embayment and are based on observations of DO versus iron concentration in groundwater wells and the output and performance of BRT DO threshold and iron concentration models. The final categories in relation to DO and iron thresholds are shown in table 2. Additionally, DO probability and iron concentration rasters are available in an associated data release (Knierim and others, 2020a), such that redox zones can be recategorized if warranted.

\section{Water-Quality Data Results}

DO concentration was lower and iron concentration was higher in the MRVA compared to the MCAQ and LCAQ (fig. 3 on sheet 1 , fig. 4 on sheet 2, fig. 5). DO concentration $(\mathrm{n}=564)$ ranged from less than 0.1 to $17.1 \mathrm{mg} / \mathrm{L}$ and the median concentration in the MRVA $(0.2 \mathrm{mg} / \mathrm{L})$ was lower than in the MCAQ (1.2 mg/L) and LCAQ (4.6 mg/L) (fig. 5).

Table 2. Redox zone categories based on predicted probability of dissolved oxygen (DO) concentration exceeding a threshold of 1 milligram per liter and based on iron concentration.

$[\mu \mathrm{g} / \mathrm{L}$, micrograms per liter; >, greater than; $<$, less than; $\leq$, less than or equal to; $\geq$, greater than or equal to; NA, not applicable]

\begin{tabular}{llc}
\hline $\begin{array}{c}\text { Redox } \\
\text { category }\end{array}$ & \multicolumn{1}{c}{$\begin{array}{c}\text { DO } \\
\text { (probability) }\end{array}$} & $\begin{array}{c}\text { Iron } \\
(\boldsymbol{\mu} \mathbf{g} / \mathbf{L})\end{array}$ \\
\hline Oxic & $>0.8$ & $<1,000$ \\
Mixed oxic & $>0.8$ & $>1,000$ \\
& $\leq 0.8$ and $\geq 0.1$ & $<500$ \\
Mixed anoxic & $\leq 0.8$ and $\geq 0.1$ & $\geq 500$ \\
Anoxic & $<0.1$ & $\mathrm{NA}$ \\
\hline
\end{tabular}



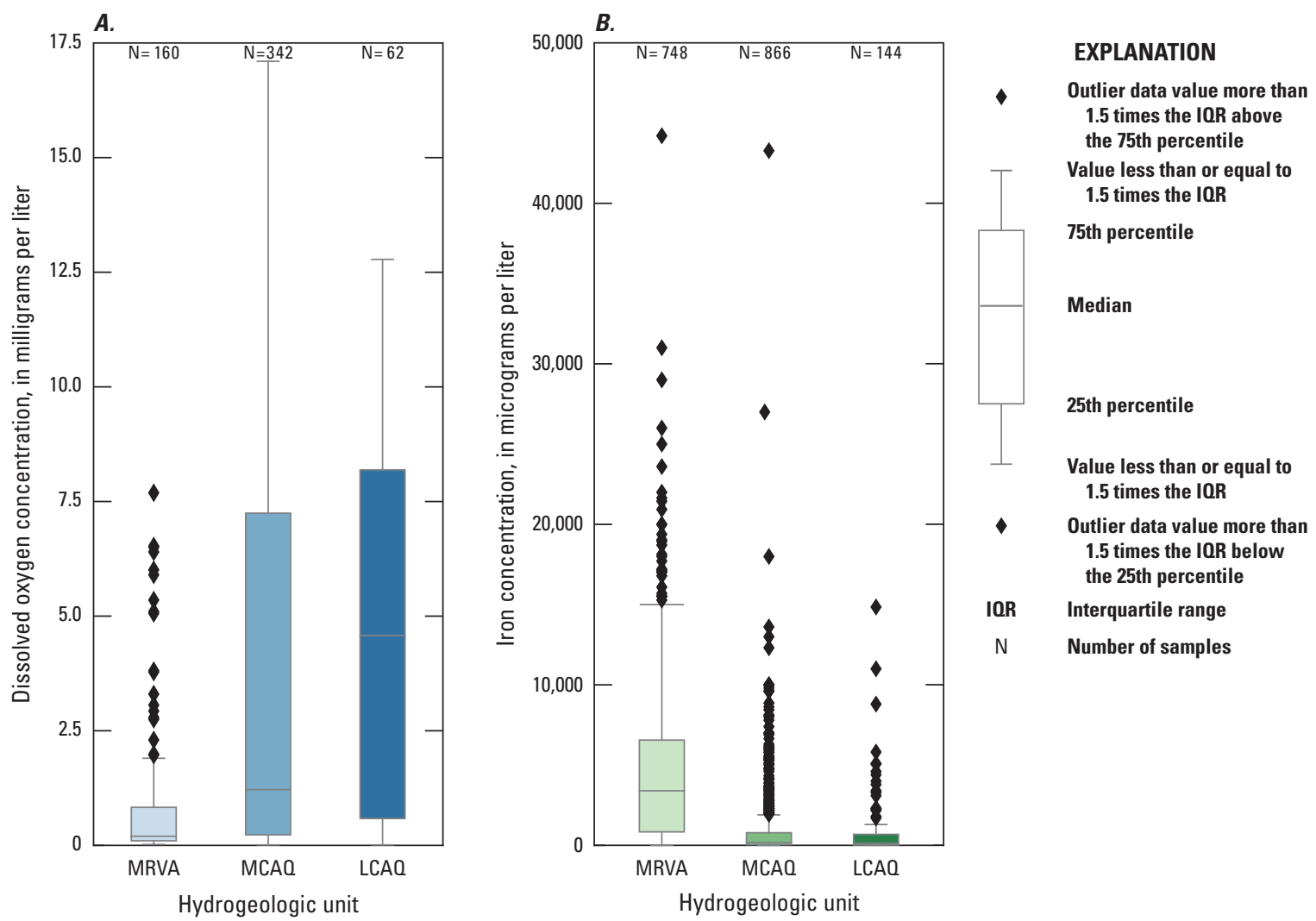

Figure 5. $A$, Dissolved oxygen and, $B$, iron concentrations in groundwater wells by hydrogeologic unit.

Many lower DO concentrations (generally less than $0.1 \mathrm{mg} / \mathrm{L}$ ) are censored values, and concentrations greater than approximately $10 \mathrm{mg} / \mathrm{L}$ are not reasonable based on saturation concentrations of DO at groundwater temperatures typical of the study area. However, because a classification BRT model was used and only the probability of exceeding a DO concentration threshold of $1 \mathrm{mg} / \mathrm{L}$ was predicted, spurious values at low or high DO concentrations were not a concern for modeling. The event rate (or proportion of samples greater than the 1-mg/L threshold) was 43 percent for training and testing data. Iron concentrations $(n=1,758)$ ranged from less than $4.0 \mu \mathrm{g} / \mathrm{L}$ (natural $\log$ of -3.78 for an imputed value of censored data) to $44,210 \mu \mathrm{g} / \mathrm{L}$ (natural $\log$ of 10.70) and the median iron concentration was higher for the MRVA $(3,294 \mu \mathrm{g} / \mathrm{L})$ than for the MCAQ $(164 \mu \mathrm{g} / \mathrm{L})$ or LCAQ $(122 \mu \mathrm{g} / \mathrm{L})$ (fig. 5). Iron concentration was greater than $100 \mu \mathrm{g} / \mathrm{L}$ in 69 percent of wells; from 51 percent in the MCAQ (layer 5) to 86 percent in MRVA wells. The $100-\mu \mathrm{g} / \mathrm{L}$ threshold is used for national classification of redox processes in principal aquifers, per McMahon and Chapelle (2008).

\section{BRT Model Results}

BRT model performance metrics are different for classification and regression models, so results obtained from the DO and iron models cannot be compared directly (table 3 ).
DO models had an area under the receiver operating characteristic curve (AUROC) of 1 for training data and an AUROC of 0.84 for holdout data, where an AUROC of 1 corresponds to a perfectly fit model (Kuhn and Johnson, 2013). For holdout data, only 12 events out of 64 were incorrectly classified as nonevents and 17 nonevents out of 49 were incorrectly classified as events for the final DO model (table 4); thus, the incorrect predictions (that is, false positive or false negatives) are outliers within each DO category (fig. 6). The final iron model had a coefficient of determination $\left(\mathrm{r}^{2}\right)$ of 0.88 for training data and an $\mathrm{r}^{2}$ of 0.49 for holdout data, with a relatively high holdout RMSE of 1.81 (table 3 ). The final iron model had lower ppb bias compared to the "best" tuned model (table 3 ). The bias correction factor was 1.82 for the final iron model, such that the goodness-of-fit for untransformed iron predictions was more scattered than the natural log predictions (fig. 7).

\section{Predictions of Dissolved Oxygen Threshold Probabilities}

The probability of predicting a DO concentration greater than $1 \mathrm{mg} / \mathrm{L}$ was low for the MRVA and lower in the central portion of the MCAQ and LCAQ compared to areas not overlain by the MRVA (fig. $8 D-F$ on sheet 1 ). DO events, indicated by predicted probabilities greater than 0.5 , tended 
Table 3. Hyperparameters for dissolved oxygen (DO) and iron boosted regression tree models for the final, variable reduced ("final"), one standard error ("1SE"), and best training ("best") models.

[Model performance parameters are provided for holdout data (unless otherwise specified. n, sample size; No. vars, number of explanatory variables; id, interaction depth; mo, minimum observations per node; sh, shrinkage (or learning rate); nt, number of trees; ppb, percent proportion bias; RMSE, root mean square error; $\mathrm{r}^{2}$, coefficient of determination; NA, not applicable]

\begin{tabular}{|c|c|c|c|c|c|c|c|c|c|c|c|c|c|c|}
\hline \multirow{2}{*}{$\begin{array}{c}\text { Response } \\
\text { variable }\end{array}$} & \multirow{2}{*}{$\begin{array}{c}n \\
\text { (training) }\end{array}$} & \multirow{2}{*}{$\begin{array}{c}n \\
\text { (holdout) }\end{array}$} & \multirow{2}{*}{ Model } & \multirow{2}{*}{$\begin{array}{l}\text { No. } \\
\text { vars }\end{array}$} & \multirow{2}{*}{ id } & \multirow{2}{*}{ mo } & \multirow{2}{*}{ sh } & \multirow{2}{*}{ nt } & \multirow{2}{*}{ ppb } & \multirow{2}{*}{$\begin{array}{l}\text { RMSE or } \\
\text { accuracy }\end{array}$} & \multicolumn{2}{|c|}{$r^{2}$} & \multirow{2}{*}{ Sensitivity } & \multirow{2}{*}{ Specificity } \\
\hline & & & & & & & & & & & Training & Holdout & & \\
\hline \multirow{4}{*}{ DO } & & & Final & 33 & 2 & 10 & 0.014 & 4,500 & 0.00 & 0.77 & NA & NA & 0.73 & 0.8 \\
\hline & 451 & 113 & $1 \mathrm{SE}$ & 130 & 2 & 10 & 0.014 & 4,500 & -0.89 & 0.76 & NA & NA & 0.73 & 0.78 \\
\hline & & & Best & 130 & 4 & 10 & 0.004 & 3,000 & 6.20 & 0.80 & NA & NA & 0.69 & 0.88 \\
\hline & & & Final & 37 & 6 & 8 & 0.012 & 2,000 & -0.01 & 1.81 & 0.88 & 0.49 & NA & NA \\
\hline \multirow[t]{2}{*}{ Iron } & 1,408 & 350 & $1 \mathrm{SE}$ & 132 & 6 & 8 & 0.012 & 2,000 & 0.19 & 1.81 & 0.90 & 0.47 & NA & NA \\
\hline & & & Best & 132 & 18 & 10 & 0.002 & 2,500 & 0.67 & 1.78 & 0.85 & 0.50 & NA & NA \\
\hline
\end{tabular}

Table 4. Observed and predicted dissolved oxygen (DO) events for holdout data.

[An event corresponds to a DO concentration greater than 1 milligram per liter at a predicted probability greater than 0.5$]$

\begin{tabular}{l|ccc}
\hline \multirow{2}{*}{ Predicted } & \multicolumn{3}{|c}{ Observed } \\
\cline { 2 - 4 } & Event & Nonevent & Total \\
\hline Event & 52 & 17 & 69 \\
Nonevent & 12 & 32 & 44 \\
Total & 64 & 49 & 113 \\
\hline
\end{tabular}

to occur on the margins of the MRVA and upland areas where MCAQ and LCAQ units crop out at the surface or are shallow (figs. 1 and 2). These predictions are supported by DO observations (fig. $3 A-B$ on sheet 1 ) and reinforce conceptual models where the MRVA is predominantly anoxic and DO concentration decreases along regional groundwater flowpaths in the Claiborne aquifers (Kingsbury and others, 2015). One large area of high DO threshold probability in the MRVA was noted in northeastern Louisiana, and although wells in the area are limited in number, DO concentrations greater than $2 \mathrm{mg} / \mathrm{L}$ have been observed (figs. $3 A$ and $8 D$ on sheet 1).

Many of the most influential variables for predicting DO (fig. 9) are interpreted as surrogates for position along the groundwater flow path. For example, the probability of DO concentration exceeding $1 \mathrm{mg} / \mathrm{L}$ was greater where groundwater altitude in 1930 was higher, which corresponds to upland areas at the margins of the Mississippi embayment that serve as recharge areas for the MCAQ and LCAQ. These results are similar to salinity predictions from BRT models where Knierim and others (2020b) found that explanatory variables that serve as surrogates for position along the groundwater flow path were important predictors of specific conductance and chloride concentrations. Therefore, results of ML modeling efforts in the Mississippi embayment indicate that as position along the groundwater flow path increases, dissolved solids increase (Knierim and others, 2020b) and DO concentration decreases.

Confidence intervals (CIs) provide a measure of uncertainty by bracketing the predictions of DO threshold probabilities with lower and upper bounds at 5th and 95th percentiles, respectively (fig. 8 on sheet 1). In the MRVA, the lower CI for DO was predominantly less than 0.1 (fig. $8 G$ ), so greater uncertainty corresponds with areas where the upper $\mathrm{CI}$ is higher (fig. $8 A$; that is, where upper minus lower $\mathrm{CI}$ is larger). Uncertainty was greatest in the MRVA in the southern part of the modeled area where the probability of a DO event was high and there were few DO samples (figs. $3 A$ and $8 A$ on sheet 1). Uncertainty was also great on the northwestern margins of the MRVA where the upper DO CI is high (fig. $8 \mathrm{~A}$ on sheet 1). In these areas, observations of DO concentration greater than $1 \mathrm{mg} / \mathrm{L}$ are limited (fig. $3 A$ on sheet 1 ). For the MCAQ and LCAQ, high DO concentrations were consistently predicted at the margins of the modeled area in the Tertiary uplands, as shown by DO threshold probabilities generally greater than 0.9 for lower and upper CIs (fig. $8 B, C, H$, $I$, on sheet 1). DO uncertainty was great in the MCAQ and LCAQ where the upper CI was high on the northwestern margin of the modeled area; in parts of this area, the lower $\mathrm{CI}$ is less than 0.1 (fig. $8 H-I$, on sheet 1 ) and the upper $\mathrm{CI}$ is greater than 0.9 (fig. $8 B-C$ on sheet 1), such that the confidence of whether a DO event is predicted or not is low.

The proportion of observed DO events was 43 percent overall, and ranged from 19 percent for groundwater wells in the MRVA to 71 percent for wells in the MCAQ (layer 7) (Knierim and others, 2020a). The proportion of predicted DO threshold probabilities above 0.5 (which would classify as an event) in raster cells varied by model layer, from 11 percent in the MRVA to 34 percent in the MCAQ (layer 7). The difference in the proportion of observed DO events (wells) versus predicted DO events (rasters) was smallest for the MRVA (19 percent event rate in wells compared to 11 percent in 

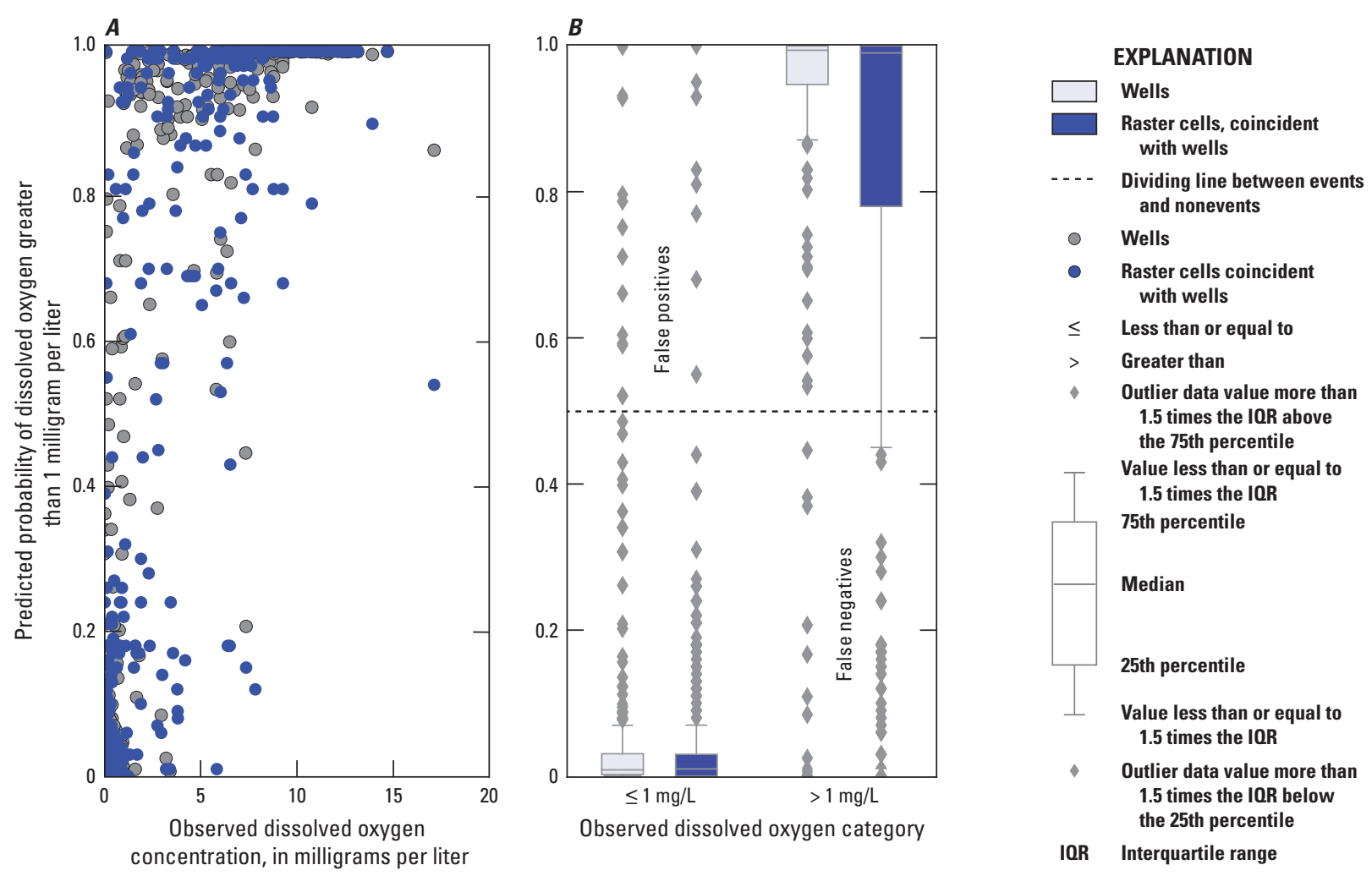

Figure 6. A, Observed dissolved oxygen (DO) concentration in groundwater wells versus predicted DO probability in wells and at raster cells coincident with wells, and $B$, boxplot showing observed DO threshold category in groundwater wells versus predicted DO probability in wells and at raster cells coincident with wells.
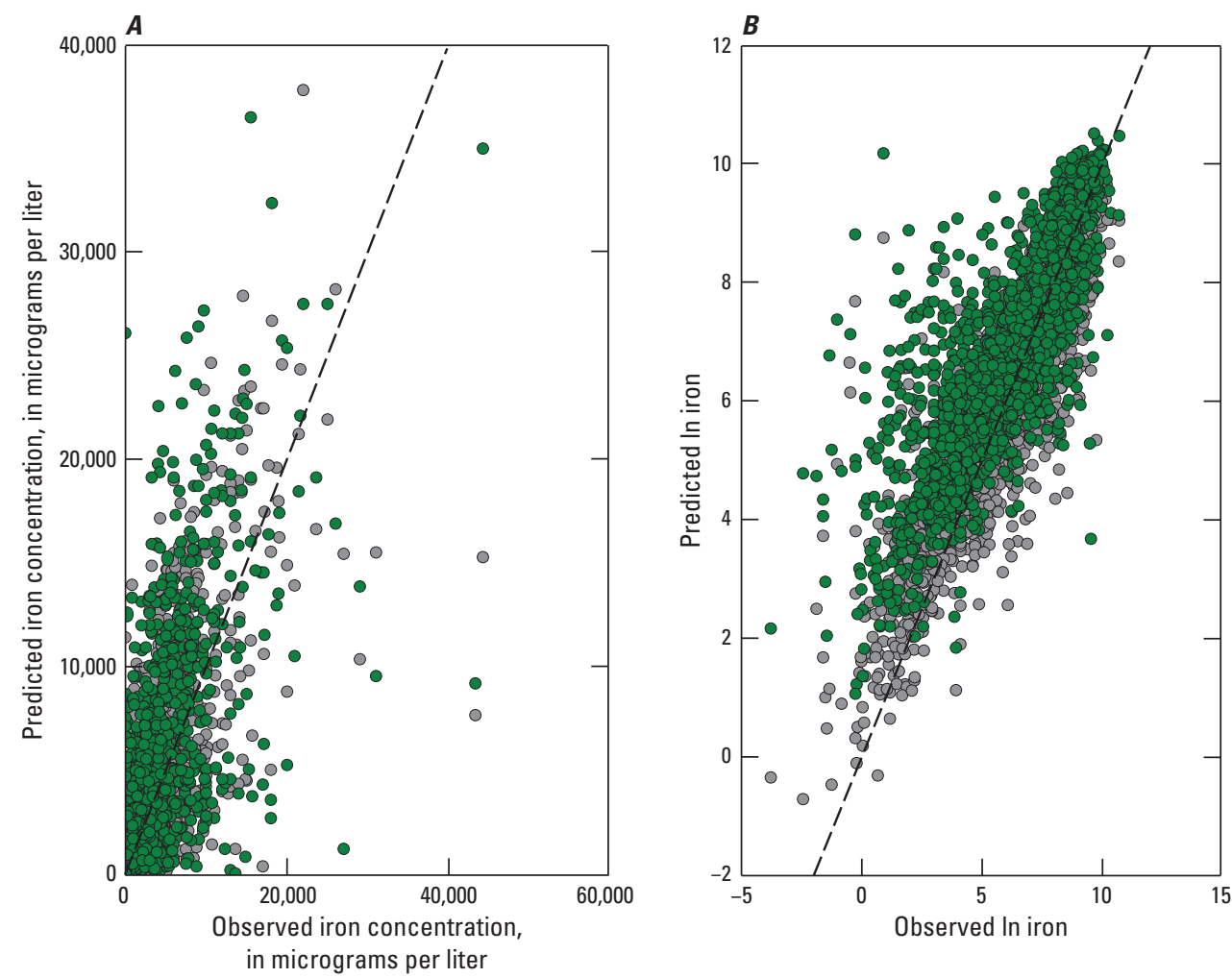

EXPLANATION

- Wells

- Raster cells coincident with wells

Figure 7. $A$, Observed versus predicted iron concentration back-transformed to units of micrograms per liter, and $B$, observed versus predicted natural $\log (\ln )$ iron concentration. 


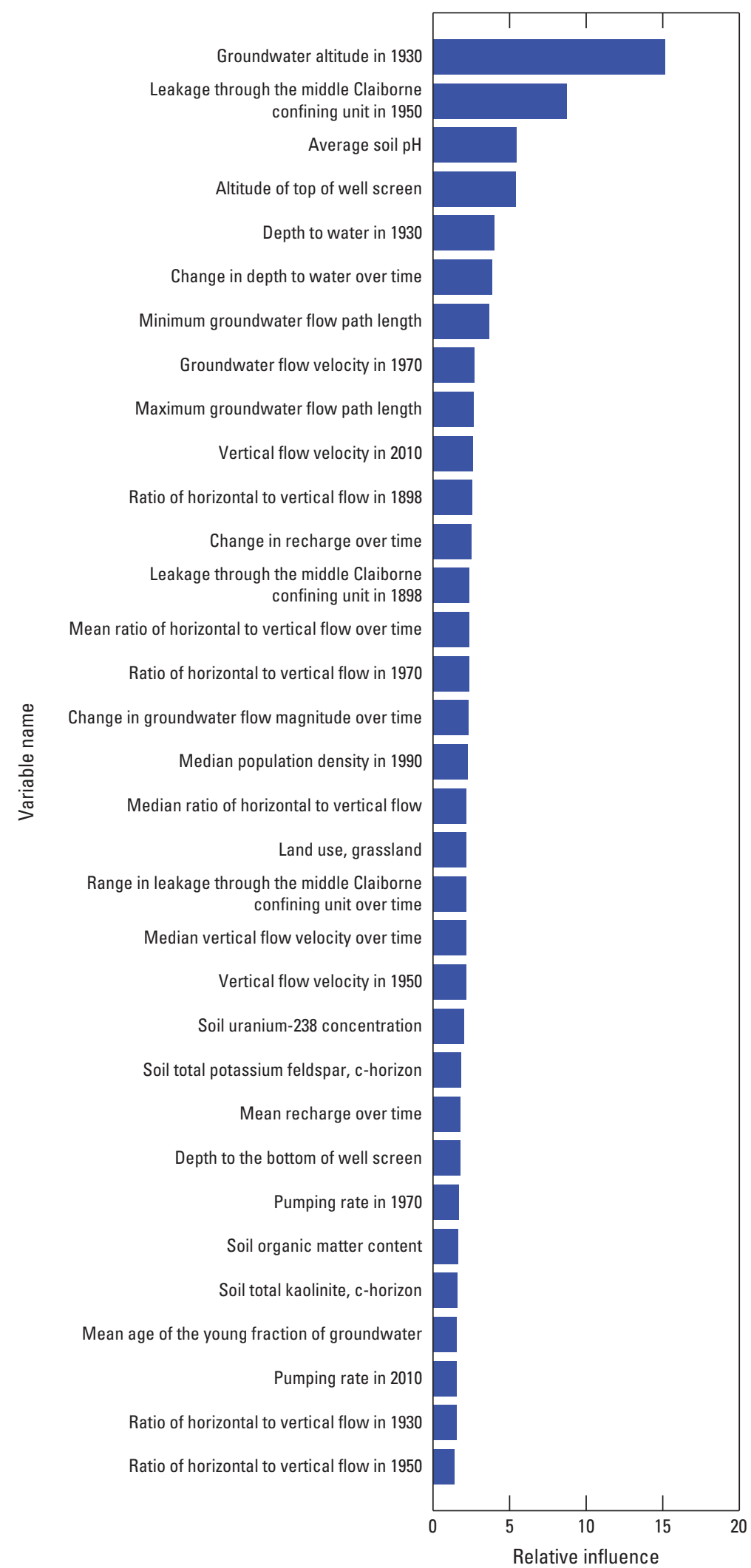

Figure 9. Relative influence of explanatory variables in the dissolved oxygen model. See Knierim and others (2020a) for an explanation of explanatory variables. 
raster cells) compared to the MCAQ and LCAQ. Although the proportion of events in prediction rasters was not as high as in the well observations, sampling may be biased - especially in the MCAQ and LCAQ - toward areas of the aquifer that are shallow, which tend to be in the recharge zone where DO is correspondingly high (fig. $3 B$ on sheet 1 ).

\section{Predictions of Iron Concentration}

Predicted iron concentrations were higher in the MRVA than in the MCAQ and LCAQ (fig. $10 D-F$ on sheet 2). In the MRVA, iron concentrations greater than $25,000 \mu \mathrm{g} / \mathrm{L}$ were measured in 0.7 percent of wells, and very high concentrations greater than $100,000 \mu \mathrm{g} / \mathrm{L}$ were not observed (fig. $4 A$ on sheet 2). Although the iron BRT model was not biased (table 3), raster cell predictions tended to be greater than predictions at groundwater wells coincident with the raster cells (figs. 7 and 11). Despite this, the total number of cells (or aquifer area) with extreme predictions was low (fig. $10 D$ on sheet 2); in the MRVA, 1.4 percent of cells had predicted concentrations greater than $25,000 \mu \mathrm{g} / \mathrm{L}$ and none were greater than $100,000 \mu \mathrm{g} / \mathrm{L}$. In the MCAQ, predicted iron concentrations were predominantly less than $5,000 \mu \mathrm{g} / \mathrm{L}$, with higher concentrations located in western Tennessee (fig. $10 E$ on sheet 2 ) and only 0.4 percent of raster cells having concentrations greater than $10,000 \mu \mathrm{g} / \mathrm{L}$ in MCAQ layer 5 . Predicted iron concentrations were lower in deeper Tertiary units, such as LCAQ layer 10 (fig. $10 F$ on sheet 2), where only 0.1 percent of raster cells had predicted concentrations greater than $10,000 \mu \mathrm{g} / \mathrm{L}$. BRT model predictions (without bias correction) at wells tended to overpredict at low iron concentrations and underpredict at high iron concentrations (fig. 11). After predictions were adjusted by using the bias correction factor, predicted iron concentrations in groundwater wells generally were higher than observed concentrations. Lastly, when the BRT model was used to predict iron concentrations at raster cells, these concentrations were higher than the predicted concentrations for the coincident wells (fig. 11). Therefore, predicted iron concentrations are characterized as overpredicted once the final BRT model is used to map iron concentration, despite the BRT model itself not being biased.

Important explanatory variables for the iron BRT model included predicted groundwater quality, hydrogeology, and position within the regional groundwater flow system (fig. 12). For example, the most important predictor of iron concentration was BRT model output of predicted groundwater specific conductance from Knierim and others (2020b) and the third most important predictor was predicted DO probability. Explanatory variables for the specific conductance BRT model are similar to those used in the DO and iron models, and ML models integrate interactions among explanatory variables into the output prediction of a response variable. Hydrogeology

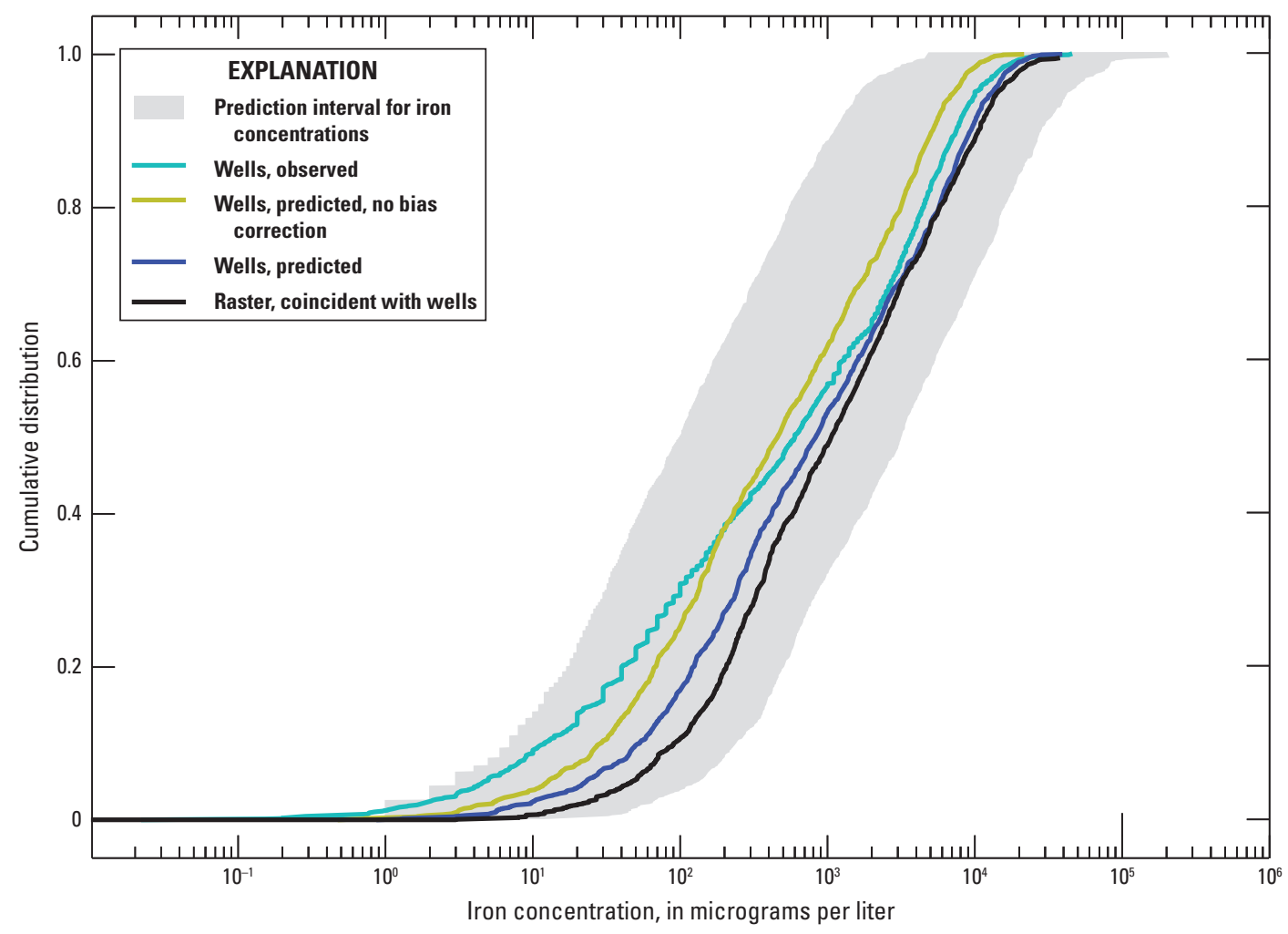

Figure 11. Cumulative distribution frequency of observed iron concentrations at wells, predicted iron concentrations at wells (with and without bias correction), and predicted iron concentrations at raster cells coincident with wells. 


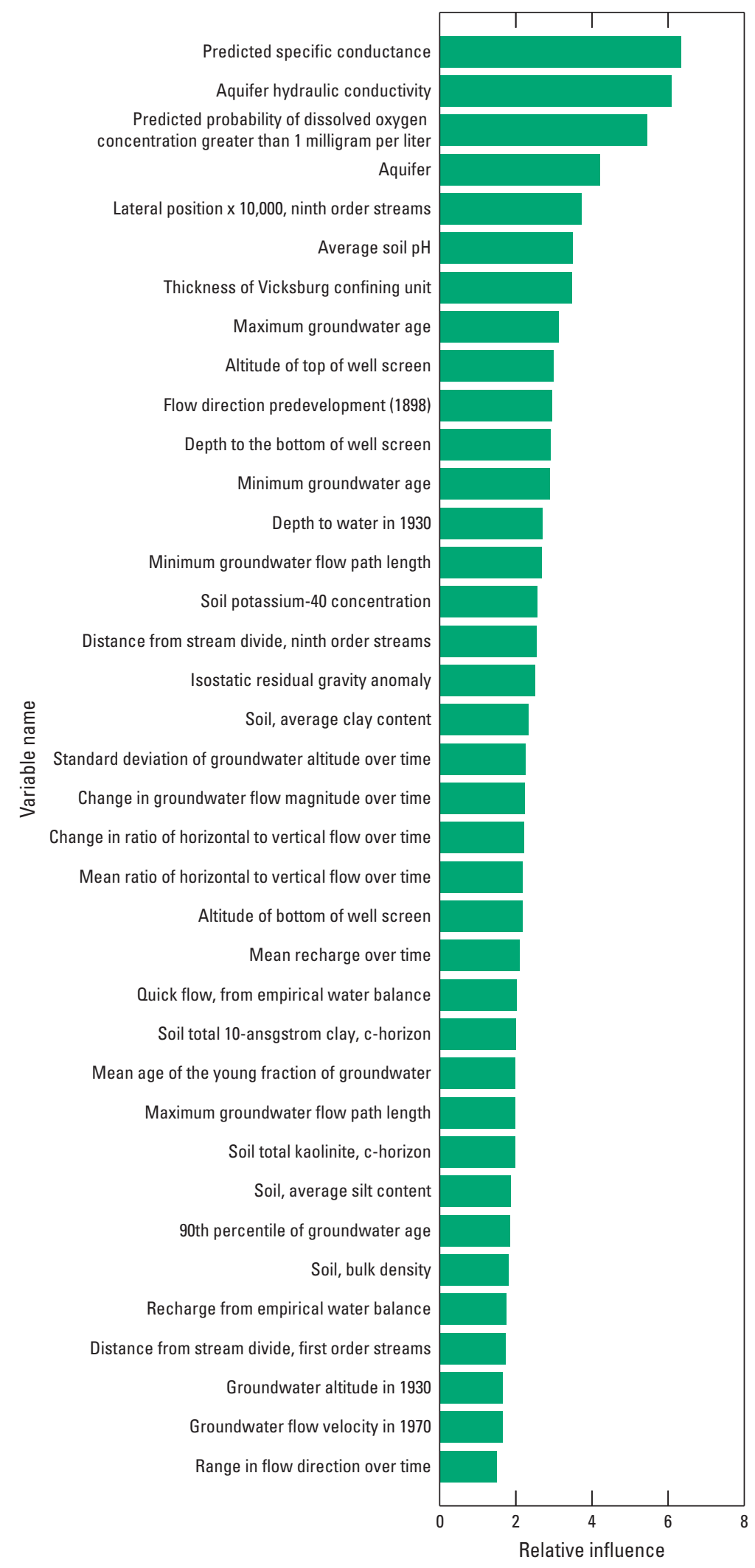

Figure 12. Relative influence of explanatory variables in the iron model. See Knierim and others (2020a) for an explanation of explanatory variables. 
such as aquifer (MRVA, MCAQ, or LCAQ) and variables that serve as surrogates for which aquifer a well is screened in, including aquifer hydraulic conductivity, were also important explanatory variables (fig. 12). Multi-order hydrologic position for ninth order streams (lateral position, ninth-order streams) was an important predictor of iron concentration and represents the location of a well relative to the Arkansas and Mississippi Rivers, which act as major groundwater flow boundaries. Predicted DO probability (fig. 9) and specific conductance (Knierim and others, 2020b) had similar important explanatory variables that represented position along the groundwater flow path, and both were found to be important predictors of iron concentration. The results of this modeling effort highlight that as groundwater residence time increases, rock-water interaction also increases, thus increasing dissolved solids (measured as specific conductance) and consuming DO; and as DO decreases, predicted iron concentration increases.

Predictions of high iron concentrations tended to have high uncertainty, with upper PIs being orders of magnitude greater than predicted iron concentrations (fig. $10 \mathrm{~A}-\mathrm{F}$ on sheet 2). Most of the very high predictions of iron concentration in the upper PIs were within the MRVA (fig. $10 A$ on sheet 2), with a maximum PI concentration of approximately $915,000 \mu \mathrm{g} / \mathrm{L}$. Despite the large magnitude of predicted high iron concentrations, the proportion of very high concentration raster cells was still relatively small, with only 1.5 percent of the cells in the MRVA upper PI exceeding 100,000 $\mu \mathrm{g} / \mathrm{L}$. Uncertainty tended to be lower in the MCAQ and LCAQ (especially along the eastern margins of the study area), such that the range between upper and lower PIs was predominantly less than $5,000 \mu \mathrm{g} / \mathrm{L}$. Although iron concentration may be overpredicted in some areas, the general proportion and spatial distribution of predicted iron concentration reflects groundwater well observations (figs. $4 A-B$ and $10 D-F$ on sheet 2). Therefore, the BRT iron models can be used to categorize qualitative redox zones but may not be appropriate for accurately predicting iron concentration at any given location.

\section{Redox Zone Categorization}

Categorical descriptions of redox conditions in the Mississippi embayment are useful for understanding the occurrence and distribution of constituents that are controlled by redox processes. Redox zones (fig. $13 D-F$ on sheet 3 ) were largely determined by predicted DO probability; predicted iron concentrations were used as an additional check for the oxic category. The MRVA was mostly anoxic (fig. $13 D$ on sheet 3 ). Oxic conditions were present mostly in the uplands of the MCAQ and LCAQ at the margins of the modeled area (fig. $13 E-F$ on sheet 3 ). The presence of mixed redox zones between the oxic and anoxic zones depended on iron concentration, which is an important indicator of where along the terminal electron acceptor sequence or redox condition groundwater may be (McMahon and Chapelle, 2008).
For describing redox conditions in groundwater aquifers across the United States, an iron concentration of $100 \mu \mathrm{g} / \mathrm{L}$ has been used as a water-quality criterion cutoff (McMahon and Chapelle, 2008). For Mississippi embayment BRT models, however, mapped iron concentrations generally were overpredicted (that is, raster predictions were higher than well predictions and observations, figs. 7 and 11) and 99.8 percent of MRVA raster cells were greater than $100 \mu \mathrm{g} / \mathrm{L}$. Therefore, a higher iron concentration threshold of $500 \mu \mathrm{g} / \mathrm{L}$ was used to separate mixed oxic and mixed anoxic categories, which helps account for raster predictions possibly being biased high. Mixed redox zones are present near the transition from oxic groundwater (in recharge areas along the margins of the MCAQ and LCAQ) to anoxic groundwater (fig. 13E-F on sheet 3$)$. In the MRVA, most of the mixed redox conditions are mixed anoxic (fig. 13D on sheet 3 ), highlighting that much of the MRVA has low DO and high iron concentrations.

The upper and lower CIs of DO threshold probability and PIs of iron concentration were used to provide bounds on the qualitative redox zones (fig. 13A-C, G-I on sheet 3). Like the redox zones, the upper and lower bounds for redox zones largely were controlled by predicted DO conditions (fig. $8 A-C$, $G-I$ sheet 1 and fig. $13 A-C, G-I$ on sheet 3 ). For the MRVA, anoxic conditions ranged from 96 percent of the aquifer area for lower prediction bounds to 23 percent for upper prediction bounds. Much of this difference was accounted for in the mixed anoxic category - for example, when anoxic and mixed anoxic zones are summed, the lower and upper bounds were 97 and 78 percent, respectively, of the MRVA area. The pattern is similar for the MCAQ (layer 5) in that the area of the aquifer categorized as anoxic ranged from 85 to 38 percent for lower and upper bounds, respectively. When summed together, mixed anoxic and anoxic zones ranged from 85 to 69 percent for lower and upper bounds, respectively.

Although there is much uncertainty about the magnitude of predicted iron concentrations in the MRVA, MCAQ, and LCAQ, there is greater confidence that more than three-fourths of these aquifers have either anoxic or mixed anoxic conditions. Thus, constituents that are affected by reducing conditions, such as manganese, might be present at high concentrations across a majority of Mississippi embayment aquifers. Despite the presence of reducing conditions in both the MRVA and Claiborne aquifers (fig. 13D-F on sheet 3), iron (fig. 4 on sheet 2), manganese, and arsenic concentrations are high predominantly in the MRVA and lower in the Claiborne aquifers (Kingsbury and others, 2015). Geologic sources of trace elements and the availability of organic carbon also control the potential for high trace element concentrations in groundwater (McMahon and Chapelle, 2008). Therefore, the presence of anoxic groundwater and the potential for reducing conditions are not the only controls on trace element concentrations. In the Mississippi embayment, differences in depositional environments and sediment mineralogy exert important controls on the occurrence and distribution of high manganese and arsenic concentrations (Parks and Carmichael, 1990; Sharif and others, 2008), as do reducing conditions found in anoxic and mixed anoxic zones. 


\section{Summary}

Redox conditions are important controls on the fate and transport of many naturally occurring and anthropogenic contaminants. To map redox zones in drinking-water aquifers in the Mississippi embayment, the U.S. Geological Survey developed ensemble machine-learning models (boosted regression trees [BRT]) to predict iron concentrations and the probability that dissolved oxygen (DO) concentrations exceeded a 1-milligram-per-liter (mg/L) threshold. DO threshold probability $(\mathrm{n}=556)$ and iron concentration $(\mathrm{n}=1,758)$ were predicted with classification and regression BRT models, respectively, using a variety of explanatory variables, including attributes associated with well geometry, surficial variables, and variables extracted from a MODFLOW-2005 groundwater-flow model for the Mississippi embayment. The final DO model had an area under the receiver operating characteristic curve of 0.84 for holdout data. The final iron model had a coefficient of determination $\left(\mathrm{r}^{2}\right)$ of 0.49 for holdout data.

Model predictions indicate DO concentrations greater than $1 \mathrm{mg} / \mathrm{L}$ are uncommon across the Mississippi River Valley alluvial aquifer (MRVA) and when exceedances do occur, they tend to be located along the margins of the aquifer. Across the middle Claiborne aquifer (MCAQ) and lower Claiborne aquifer (LCAQ), DO concentrations greater than $1 \mathrm{mg} / \mathrm{L}$ tend to be located along the margins of the Mississippi embayment in areas not overlain by the MRVA. Predicted iron concentrations were higher in the MRVA than in the MCAQ and LCAQ. Iron concentration predictions had high uncertainty, owing to upper prediction interval concentrations being very large in magnitude. Although the iron BRT model was not biased, predicted iron concentrations were greater in raster cells than at coincident groundwater wells. Despite the large magnitude of overpredictions, the proportion of the aquifer predicted to have very high iron concentrations (over 100,000 micrograms per liter) was relatively small. Therefore, BRT iron models were able to predict the spatial distribution and general variability in low and high iron concentrations and can be used to categorize redox zones. Output from the iron BRT models may not be appropriate for accurately predicting iron concentration in any one well.

Where the predicted probability of exceeding a DO concentration of $1 \mathrm{mg} / \mathrm{L}$ was greater than 0.8 and predicted iron concentration was less than 1,000 micrograms per liter, Mississippi embayment aquifers are considered oxic, and these conditions mostly were in the uplands of the MCAQ and LCAQ at the margins of the modeled area. The MRVA was mostly anoxic, a category defined by predicted DO threshold probabilities less than 0.1 . The predictions and redox zones support conceptual models of redox conditions in the Mississippi embayment, where the MRVA is predominantly anoxic with high iron concentrations. For the Claiborne aquifers, as groundwater flows along regional flow paths toward the axis of the Mississippi embayment in the approximate location of the Mississippi River, the residence time in the aquifer increases, DO is consumed, and groundwater transitions from oxic to anoxic.

\section{References Cited}

Borrok, D.M., Lenz, R.M., Jennings, J.E., Gentry, M.L., Steensma, J., and Vinson, D.S., 2018, The origins of high concentrations of iron, sodium, bicarbonate, and arsenic in the Lower Mississippi River alluvial aquifer: Applied Geochemistry, v. 98, p. 383-392, accessed May 2019 at https://doi.org/10.1016/j.apgeochem.2018.10.014.

Chapelle, F.H., McMahon, P.B., Dubrovsky, N.M., Fujii, R.F., Oaksford, E.T., and Vroblesky, D.A., 1995, Deducing the distribution of terminal electron-accepting processes in hydrologically diverse groundwater systems: Water Resources Research, v. 31, no. 2, p. 359-371, accessed October 2009 at https://doi.org/10.1029/94WR02525.

Clark, B.R., and Hart, R.M., 2009, The Mississippi Embayment Regional Aquifer Study (MERAS)_Documentation of a groundwater-flow model constructed to assess water availability in the Mississippi embayment: U.S. Geological Survey Scientific Investigations Report 2009-5172, 62 p., accessed August 5, 2015, at https://doi.org/10.3133/ $\operatorname{sir} 20095172$.

Clark, B.R., Hart, R.M., and Gurdak, J.J., 2011, Groundwater availability of the Mississippi embayment: U.S. Geological Survey Professional Paper 1785, 62 p., accessed July 29, 2015, at https://doi.org/10.3133/pp1785.

DeSimone, L.A., Pope, J.P., and Ransom, K.M., 2020, Machine-learning models to map $\mathrm{pH}$ and redox conditions in groundwater in a layered aquifer system, Northern Atlantic Coastal Plain, eastern USA: Journal of Hydrology. Regional Studies, v. 30, p. 100697, accessed August 2020 at https://doi.org/10.1016/j.ejrh.2020.100697.

Duan, N., 1983, Smearing Estimate-A nonparametric retransformation method: Journal of the American Statistical Association, v. 78, no. 383, p. 605-610, accessed July 2017 at https://doi.org/10.1080/01621459.1983.10478017.

Elith, J., Leathwick, J.R., and Hastie, T., 2008, A working guide to boosted regression trees: Journal of Animal Ecology, v. 77, no. 4, p. 802-813, accessed June 2015 at https://doi.org/10.1111/j.1365-2656.2008.01390.x.

Friedman, J.H., 2001, Greedy function approximationA gradient boosting machine: Annals of Statistics, v. 29, no. 5, p. 1189-1232, accessed June 2015 at https://doi.org/10.1214/aos/1013203451.

Hart, R.M., Clark, B.R., and Bolyard, S.E., 2008, Digital surfaces and thicknesses of selected hydrogeologic units within the Mississippi Embayment Regional Aquifer Study (MERAS): U.S Geological Survey Scientific Investigations Report 2008-5098, accessed August 28, 2015, at https://doi.org/10.3133/sir20085098. 
Haugh, C.J., Killian, C.D., and Barlow, J.R.B., 2020a, MODFLOW-2005 model used to evaluate water-management scenarios for the Mississippi Delta: U.S. Geological Survey data release, accessed July 1, 2020, at https://doi.org/10.5066/P9906VM5.

Haugh, C.J., Killian, C.D., and Barlow, J.R.B., 2020b, Simulation of water-management scenarios for the Mississippi Delta: U.S. Geological Survey Scientific Investigations Report 2019-5116, accessed April 3, 2020, at https://doi.org/10.3133/sir20195116.

Haugh, C.J., Knierim, K., and Kingsbury, J.A., 2020c, Simulated groundwater residence times in two principal aquifers of the Mississippi embayment physiographic region: U.S. Geological Survey data release, accessed July 1, 2020, at https://doi.org/10.5066/P9X513WO.

Hosman, R.L., and Weiss, J.S., 1991, Geohydrologic units of the Mississippi Embayment and Texas coastal uplands aquifer systems, south-central United States: U.S. Geological Survey Professional Paper 1416-B., accessed July 29, 2016, at https://doi.org/10.3133/pp1416B.

Kingsbury, J.A., Barlow, J.R.B., Jurgens, B.C., McMahon, P.B., and Carmichael, J.K., 2017, Fraction of young water as an indicator of aquifer vulnerability along two regional flow paths in the Mississippi embayment aquifer system, southeastern USA: Hydrogeology Journal, v. 25 , no. 6 , p. 1661-1678, accessed January 2018 at https://doi.org/10.1007/s10040-017-1566-4.

Kingsbury, J.A., Barlow, J.R., Katz, B.G., Welch, H.L., Tollett, R.W., and Fahlquist, L.S., 2015, The quality of our Nation's waters - Water quality in the Mississippi embayment-Texas coastal uplands aquifer system and Mississippi River Valley alluvial aquifer, south-central United States, 1994-2008: U.S. Geological Survey Circular 1356, 84 p., accessed December 7, 2015, at https://doi.org/10.3133/cir1356.

Knierim, K.J., Kingsbury, J.A., and Haugh, C.J., 2020a, Machinelearning model predictions and rasters of dissolved oxygen probability, iron concentration, and redox conditions in groundwater in the Mississippi River Valley alluvial and Claiborne aquifers: U.S. Geological Survey data release, accessed November 1, 2020, at https://doi.org/10.5066/P9N108JM.

Knierim, K.J., Kingsbury, J.A., Haugh, C.J., and Ransom, K.M., 2020b, Using boosted regression tree models to predict salinity in Mississippi embayment aquifers, central United States: Journal of the American Water Resources Association, accessed November 1, 2020, at https://doi.org/10.1111/1752-1688.12879.
Kresse, T.M., Hays, P.D., Merriman-Hoehne, K.R., Gillip, J.A., Fugitt, D.T., Spellman, J.L., Nottmeier, A.M., Westerman, D.A., Blackstock, J.M., and Battreal, J.L., 2014, Aquifers of Arkansas - Protection, management, and hydrologic and geochemical characteristics of groundwater resources in Arkansas: U.S. Geological Survey Scientific Investigations Report 2014-5149, 360 p., accessed November 13, 2014, at https://doi.org/10.3133/sir20145149.

Kuhn, M., and Johnson, K., 2013, Applied predictive modeling: New York, N. Y., Springer, 595 p., accessed May 2015 at https://doi.org/10.1007/978-1-4614-6849-3.

Kuhn, M., Wing, J., Weston, S., Williams, A., Keefer, C., Engelhardt, A., Cooper, T., Mayer, Z., Kenkel, B., and Benesty, M., The R. Core Team, Lescarbeau, R., Ziem, A., Scrucca, L., and others, 2019, caret: Classification and regression training, version 6.0-85, accessed May 1, 2020, at https://cran.r-project.org/web/packages/caret/index.html.

Maupin, M.A., and Barber, N.L., 2005, Estimated withdrawals from principal aquifers in the United States, 2000: U.S. Geological Survey Circular 1279, 47 p., accessed December 8, 2016, at https://doi.org/10.3133/cir1279.

McMahon, P.B., and Chapelle, F.H., 2008, Redox processes and water quality of selected principal aquifer systems: Ground Water, v. 46, no. 2, p. 259-271, accessed January 2014 at https://doi.org/10.1111/j.17456584.2007.00385.x.

Nolan, B.T., Fienen, M.N., and Lorenz, D.L., 2015, A statistical learning framework for groundwater nitrate models of the Central Valley, California, USA: Journal of Hydrology (Amsterdam), v. 531, no. 3, p. 902-911, accessed July 2016 at https://doi.org/10.1016/j.jhydrol.2015.10.025.

Parks, W.S., and Carmichael, J.K., 1990, Geology and ground-water resources of the Memphis Sand in western Tennessee: U.S. Geological Survey Water-Resources Investigations Report 88-4182, accessed June 15, 2020, at https://doi.org/10.3133/wri884182.

Python Software Foundation, 2019, Python language reference, version 3.7: Python Software Foundation software release, accessed April 19, 2016, at https://www.python.org.

R Core Team, 2019, R-A language and environment for statistical computing: Vienna, Austria, R Foundation for Statistical Computing. 
Ransom, K.M., Nolan, B.T., Traum, J.A., Faunt, C.C., Bell, A.M., Gronberg, J.A.M., Wheeler, D.C., Rosecrans, C.Z., Jurgens, B., Schwarz, G.E., Belitz, K., Eberts, S.M., Kourakos, G., and Harter, T., 2017, A hybrid machine learning model to predict and visualize nitrate concentration throughout the Central Valley aquifer, California, USA: The Science of the Total Environment, v. 601-602, p. 1160-1172, accessed August 2017 at https://doi.org/10.1016/j.scitotenv.2017.05.192.

Ridgeway, G., 2019, gbm-Generalized boosted regression models, version 2.1.5: R Foundation for Statistical Computing software release, accessed October 13, 2019, at https://cran.r-project.org/web/packages/gbm/gbm.pdf.

Rosecrans, C.Z., Nolan, B.T., and Gronberg, J., 2017, Prediction and visualization of redox conditions in the groundwater of Central Valley, California: Journal of Hydrology (Amsterdam), v. 546, p. 341-356, accessed February 2018 at https://doi.org/10.1016/j.jhydrol.2017.01.014.

Saucier, R.T., 1994, Geomorphology and Quaternary geologic history of the lower Mississippi Valley: U.S. Army Corps of Engineers report, $414 \mathrm{p}$.
Sharif, M.U., Davis, R.K., Steele, K.F., Kim, B., Hays, P.D., Kresse, T.M., and Fazio, J.A., 2008, Distribution and variability of redox zones controlling spatial variability of arsenic in the Mississippi River Valley alluvial aquifer, southeastern Arkansas: Journal of Contaminant Hydrology, v. 99, no. 1-4, p. 49-67, accessed February 2014 at https://doi.org/10.1016/j.jconhyd.2008.03.001.

U.S. Environmental Protection Agency, 2013, Safe Drinking Water Information System (SDWIS): U.S. Environmental Protection Agency online database, accessed November 28, 2017, at https://www.epa.gov/enviro/sdwissearch.

U.S. Geological Survey, 2016, National Map 3DEP products and services, 1/3 arc-second digital elevation model: U.S. Geological Survey online database, accessed February 5, 2016, at https://viewer.nationalmap.gov/basic/? basemap $=\mathrm{b} 1 \&$ category $=$ ned, nedsrc $\&$ title $=3$ DEP $\% 20$ View.

U.S. Geological Survey, 2017, USGS water data for the Nation: U.S. Geological Survey National Water Information System database, accessed August 12, 2018, at https://doi.org/10.5066/F7P55KJN. 
For more information about this publication, contact

Director, Lower Mississippi Gulf Water Science Center U.S. Geological Survey

640 Grassmere Park, Suite 100

Nashville, TN 37211

(615) $837-4700$

For additional information visit https://www.usgs.gov/centers/lmg-water

Publishing support provided by Lafayette Publishing Service Center 
